Gorontalo Accounting Journal

https://jurnal.unigo.ac.id/index.php/gaj

Vol. 4, No. 2, October 2021

P-ISSN: 2614-2074, E-ISSN: 2614-2066

Nationally Accredited Journal, Decree No.36/E/KPT/2019 Sinta 4

\title{
Penyusutan Aset Tetap Kenderaan Bermotor
}

Julie Abdullah', Wahyudin Hasan ${ }^{2}$, Azwar Djarangkala ${ }^{3}$

1,2,3Universitas Gorontalo, J1. A. A Wahab, Kecamatan Limboto, Kabupaten Gorontalo/Indonesia

Email: julieabdullah99@gmail.com¹, wahyudinhasan99@gmail.com², ardjarangkala@gmail.com ${ }^{3}$

Citation: Abdullah, J., Hasan, W., \& Djarangkala, A. (2021). Penyusutan Aset Tetap Kenderaan Bermotor. Gorontalo Accounting Journal 4 (2), 197-206. DOI: $\underline{10.32662 / g a j . v 4 i 2.1786}$

\section{Artikel info}

Artikel history:

Received: 23-09-2021

Revised: 11-10-2021

Accepted: $17-10-2021$
Abstract. Fixed assets of motorized vehicles have a relatively short useful life compared assets such as structures and buildings. Besides from that, this object is very prone to loss, damage, and constant depreciation. To minimize the risk in estimating depreciation of fixed assets on a time frame scale, good asset plan is necessary. The goal of this article is to find out which Bone Bolango Regency Financial and Asset Management Agency manages the depreciation of motorized vehicle in the financial statements. The analysis tool use the straight-line method to assess fixed assets, as well as the method used is quantitative descriptive, the aim of obtaining an objective picture of the implementation of depreciation of fixed assets in accordance with Government Regulation Number 71 of 2010 based on financial statement data period 2020. From the results of the research showed that In the activity of determining the value of BPKAD Bone Bolango district not yet in accordance with Government Accounting Standards No. 07 contained in Government Regulation Number 71 of 2010 concerning Government Accounting Standards. In principles of the accounting activity of depreciation of assets, primarily motorized vehicles, the activity of determining the useful life of assets and the depreciation of assets calculation activities of institutional motorized vehicle assets has matched PSAP number 7.

Abstrak. Aset tetap kenderaan bermotor memiliki masa manfaaat yang relative singkat dibandingkan aset tetap seperti gedung dan bangunan. Disamping itu aset ini sangat rentan kehilangan, rusak, serta mengalami penyusutan yang terus menerus. Diperlukan pengelolaan aset yang baik guna meminimalisir kesalahan penilaian penyusutan aset tetap setiap periode. Tujuan penulisan artikel ini untuk mengetahui penerapan penyusutan aset tetap kenderaan bermotor dalam laporan keuangan Badan Pengelola Keuangan dan Aset Daerah Kabupaten Bone Bolango. Metode yang digunakan yaitu deskriptif kuantitatif dengan alat analisis menggunakan metode garis lurus sebagai metode dalam menilai penyusutan aset tetap, tujuannya untuk memperoleh gambaran objektif mengenai penerapan penyusutan aset tetap sesuai Peraturan 
Pemerintah Nomor 71 tahun 2010 berdasarkan data laporan keuangan periode 2020. Dari hasil riset menunjukkan bahwa dalam aktivitas penentuan nilai buku aset BPKAD Kabupaten Bone Bolango belum sesuai Standar Akuntansi Pemerintah No. 07 yang tertuang pada Peraturan Pemerintah Nomor 71 Tahun 2010 tentang Standar Akuntansi Pemerintah. Adapun untuk aktivitas akuntansi penyusutan aset khususnya kenderaan bermotor, Aktivitas penetapan masa manfaat aset serta aktivitas perhitungan penyusutan aset kenderaan bermotor secara kelembagaan telah sesuai PSAP Nomor 7.

\section{Keywords:}

Penyusutan;

Aset Tetap;

Kenderaan

Bermotor
Coresponden author:

julieabdullah99@gmail.com

\section{Pendahuluan}

Era globalisasi saat ini menuntut tercapainya good government melalui sistem pemerintahan yang baik, yaitu melalui terciptanya transparansi, akuntabilitas, serta efektifitas dan efisiensi dalam pengelolaan keuangan publik. Pencapaian sistem tata kelola yang baik memerlukan perubahan akuntansi publik karena proses akuntansi menciptakan informasi keuangan bagi pihak yang berbeda. Perubahan pada bidang akuntansi ini harus dilandasi landasan yang kokoh, yakni Standar Akuntansi Pemerintahan atau disingkat SAP. Standar ini dimaksudkan sebagai pedoman dasar penyusunan serta penyajian rekening pemerintah. Sejak 22 Oktober 2010, pemerintah telah menerbitkan SAP yang ditetapkan dengan PP Nomor 71 Tahun 2010, mengganti PP Nomor 24 Tahun 2005 tentang hal yang sama.

Didalam laporan keuangan, salah satu elemen yang terpenting yakni aset. Keberadaan aset didalam organisasi pemerintahan dinilai begitu penting, sebab aset tetap adalah sarana utama penunjang aktivitas pemerintahan. Disamping itu, aset tetap diharapkan memberikan manfaat dimasa akan datang. Organisasi pemerintah jika tidak ditunjang oleh aset tetap, maka kegiatan operasional dapat dipastikan akan terganggu. Pengelolaan aset tetap juga perlu perhatian, sebab jika aset tetap tidak dikelola secara baik berdasarkan standar yang telah berlaku, maka dipastikan opini yang diberikan BPK akan berpengaruh, sebab aset tetap adalah bagian yang begitu signifikan didalam laporan keuangan (Rais et al., 2020).

Dari berbagai laporan keuangan, neraca bagian terpenting karena menggambarkan posisi aset, kewajiban, serta ekuitas dalam entitas organisasi. Didalam neraca terdapat aset yang sangat berkontribusi dimasa mendatang dan memberikan manfaat ekonomi bagi entitas organisasi. Ini sejalan dengan pengertian aset dalam SAP PP No. 71 Tahun 2010 dalam PSAP No. 1 Paragraf 8, dimana: "Aset adalah sumber daya ekonomik yang dikuasai atau dimiliki oleh entitas organisasi pemerintah sebagai akibat peristiwa dimasa lalu dan dari manfaat ekonomi dan atau sosial di masa mendatang yang diharapkan oleh pemerintah dan masyarakat serta dapat diukur dalam satuan moneter, termasuk sumber daya non-keuangan yang diperlukan untuk memberikan layanan kepada masyarakat umum dan sumber daya yang dilestarikan tetap karena alasan sejarah dan budaya. Aset menurut tingkat likuiditas dan masa manfaatnya dapat dibagi menjadi aset lancar dan aset tetap: aset jangka pendek yang sangat likuiditas memiliki masa manfaat kurang dari satu tahun dan aset dengan tingkat likuiditas di bawah aset lancar memiliki masa manfaat lebih dari satu tahun. Sedangkan aset 
yang tidak termasuk dalam kriteria aset tetap atau aset lancar diklasifikasikan dalam aset lain-lain.

Pemerintah daerah memiliki ketentuan lebih lanjut tentang penggunaan SAP Berbasis Akrual Peraturan Menteri Dalam Negeri (Permendagri) Nomor 64 Tahun 2013. Ada dua dalam Ordonansi Badan yang bertanggung jawab atas penyusunan laporan keuangan, yaitu: 1. Unit pelaporan adalah unit pemerintah yang terdiri dari satu atau lebih unit akuntansi atau unit pelaporan yang diwajibkan oleh ketentuan peraturan perundang-undangan menghasilkan laporan pertanggungjawaban berupa laporan keuangan tahunan yang disampaikan; dan 2 . Unit akuntansi adalah unit pemerintahan yang menggunakan rumah tangga/pengguna barang yang wajib menyelenggarakan pembukuan dan menyusun laporan keuangan yang digabungkan dengan unit pelaporan.

Laporan keuangan pemerintah daerah Kabupaten Bone Bolango mendapat predikat WDP selama kurun waktu tahun 2009-2012 dan memperoleh opini WTP pada kurun waktu tahun 2013-2019. Namun dengan pencapaian ini tidak berarti laporan keuangan pemerintah Kabupaten Bone Bolango bebas dari persoalan sebab tidak dapat dipungkiri masih terdapat temuan yang signifikan, antara lain terkait permasalahan yang terjadi berdasarkan siaran pers penyampaian hasil penyidikan LKPD Kabupaten Bone Bolango TA 2018 oleh perwakilan BPK RI Provinsi Gorontalo dimana dalam mematuhi peraturan perundang-undangan dan sistem pengendalian internal masih perlu mendapat perhatian, termasuk pengelolaan aset tetap, peralatan dan mesin milik Pemerintah Kabupaten Bone Bolango yang masih belum tertip (http://gorontalo.bpk.id). Aset tetap yang berada di bawah penguasaan suatu instansi pemerintah harus dipertanggungjawabkan berdasarkan standar akuntansi pemerintahan. Penatausahaan harta tetap oleh penyelenggara negara diatur dalam PSAP Nomor 07 mengenai Akuntansi Harta Tetap. Harta dalam pengertian PSAP 07 yaitu harta berwujud dengan masa manfaat lebih dari dua belas bulan atau yang dimaksudkan untuk kegiatan pemerintah atau untuk digunakan oleh masyarakat umum. Selain itu, kebijakan pencatatan maupun pengalokasian aset tetap berdasarkan pada nilai historis yaitu nilai saat diperoleh (at cost) aset tersebut. Nilai perolehan yang dimaksud yakni total keseluruhan biaya yang dikeluarkan untuk mendapatkan aset tetap tersebut ditambah keseluruhan biaya sampai dengan aset tersebut siap untuk digunakan (Hasan \& Lamatenggo, 2018). Perolehan harta berupa aset tetap juga memerlukan investasi yang signifikan, manajemen pengelolaan aset yang baik, serta penerapan prosedural yang handal sesuai ketentuan pernyataan akuntansi yang umum yang mengatur tentang perlakuan akuntansi terhadap aset tetap mulai dari proses pengakuan, penentuan nilai yang tercatat, serta penentuan dan perlakuan akuntansi atas penilaian kembali dan penurunan nilai tercatat aset tetap (Rais et al., 2020).

Beberapa riset yang pernah dilakukan seperti penelitian (Khafiyya, 2016) menunjukkan hasil bahwa perhitungan aset tetap (jeep, speed boat, dan mesin ketik manual standar serta portable) belum sesuai dengan PSAP Nomor 07. Lebih lanjut riset yang dilakukan oleh (Putri et al., 2016) memberikan hasil bahwa penerapan aset tetap pada BPBD Kabupaten Tegal sebagiannya tidak sesuai dengan PSAP Nomor 07.

Hasil riset yang berbeda dikemukakan oleh (Biswan \& Falaqi, 2018) dimana hasil riset yang dilakukan pada pemerintah Kabupaten Boyolali menunjukkan hasil yakni diperlukan dukungan lingkungan penerapan praktik akuntansi yang lebih baik yakni informasi BAST lebih rinci, pengecekan ulang pada tiap SKPD mengenai belanja modal dan klasifikasinya, dan penjelasan saldo akun aset tetap, terutama biaya-biaya serta mutasi aset tetap. 
Dengan berlandaskan beberapa permasalahan yang telah diuraikan serta beberapa perbedaan hasil riset yang pernah dilakukan maka tujuan yang hendak dicapai dari artikel ini yakni untuk mengetahui penerapan penyusutan aset tetap kenderaan bermotor pada Dinas BPKAD Kabupaten Bone Bolango.

\section{Metode Penelitian}

Metode dalam pelaksanaan riset ini menggunakan metode deskriptif kuantitatif. Adapun alat analisis untuk menilai penyusutan aset tetap kenderaan bermotor yaitu menggunakan metode garis lurus dengan tujuan untuk memperoleh gambaran yang objektif mengenai penerapan penyusutan aset tetap sesuai Peraturan Pemerintah No. 71 Tahun 2010 yang diterapkan di Dinas BPKAD Kabupaten Bone Bolango berdasarkan data laporan keuangan periode 2020. Tata cara yang ditempuh untuk memperoleh sumber data yakni dengan observasi langsung, dokumentasi serta wawancara dengan pihak terkait.

$$
\text { Penyusutan per periode }=\text { Harga Perolehan }- \text { Estimasi Nilai Residu }
$$

Estimasi Masa Manfaat

Biaya-biaya yang digunakan hingga memperoleh Harga Perolehan kenderaan bermotor yaitu: harga pembelian, biaya angkut, biaya instalasi, biaya asuransi, biaya balik nama dan biaya lain-lain. Sehingga rumus untuk mencari Nilai perolehan ialah : jumlah harga beli ditambah biaya keseluruhan dari transaksi pembelian hingga aset siap digunakan.

\section{Hasil Dan Pembahasan}

Hasil wawancara pada BPKAD Kabupaten Bone Bolango diperoleh informasi melalui keterangan manajer barang bahwa secara keseluruhan pengelolaan aset tetap dikelola melalui aplikasi SIMDA. Seluruh aset memiliki nilai masa manfaat yang sesuai keputusan Menkeu No. 59/KMK.6/2013 mengenai tabel masa manfaat.

Perhitungan penyusutan aset tetap dilakukan dengan metode garis lurus sebagai berikut:

Tabel 1 Penyusutan Aset Tetap dengan metode garis lurus "Straight line Metodh"

\begin{tabular}{|c|c|c|c|c|c|c|c|}
\hline $\begin{array}{c}\text { Nama } \\
\text { Aset }\end{array}$ & Tahun & $\begin{array}{c}\text { Nilai } \\
\text { Perolehan }\end{array}$ & $\begin{array}{c}\text { Estimasi } \\
\text { Nilai } \\
\text { Residu }\end{array}$ & $\underset{\text { Manfaat }}{\text { Nilai }}$ & $\begin{array}{c}\text { Penyusutan } \\
\text { /tahun }\end{array}$ & $\begin{array}{c}\text { Akumulasi } \\
\text { Nilai } \\
\text { Penyusutan }\end{array}$ & Nilai Buku \\
\hline \multirow{8}{*}{$\begin{array}{l}\text { Sepeda } \\
\text { Motor }\end{array}$} & 0 & & & & & & Rp 14.545.000 \\
\hline & 1 & Rp 14.545.000 & $\mathrm{Rp}-$ & 7 & Rp 2.077.857 & Rp 2.077 .857 & Rp 12.467.143 \\
\hline & 2 & Rp 14.545.000 & $\mathrm{Rp}-$ & 7 & Rp 2.077.857 & $\operatorname{Rp} 4.155 .714$ & Rp 10.389.286 \\
\hline & 3 & Rp 14.545.000 & $\mathrm{Rp}-$ & 7 & Rp 2.077.857 & Rp 6.233 .571 & Rp 8.311 .429 \\
\hline & 4 & Rp 14.545.000 & $\mathrm{Rp}-$ & 7 & Rp 2.077 .857 & Rp 8.311 .429 & Rp 6.233.571 \\
\hline & 5 & Rp 14.545 .000 & $\mathrm{Rp}-$ & 7 & Rp 2.077.857 & $\operatorname{Rp} 10.389 .286$ & $\operatorname{Rp} 4.155 .714$ \\
\hline & 6 & Rp 14.545 .000 & $\mathrm{Rp}-$ & 7 & Rp 2.077.857 & $\operatorname{Rp} 12.467 .143$ & Rp 2.077.857 \\
\hline & 7 & Rp 14.545 .000 & $\mathrm{Rp}-$ & 7 & Rp 2.077.857 & $\operatorname{Rp} 14.545 .000$ & $\mathrm{Rp}$ \\
\hline
\end{tabular}

Sumber: Olahan Data, 2021

Data tabel 1 menunjukkan bahwa harga perolehan Sepeda Motor berdasarkan sub buku besar yang telah sesuai dengan KIB yakni sebesar Rp 14.545.000, yang dibeli tahun 2014 dan aset dalam kondisi baik, prinsip akuntansi dan penilaian masa manfaat berdasarkan Permenkeu 59/KMK.6/2013 melihat 
masa manfaat sepeda motor untuk angkutan darat bermotor 7 tahun yang lalu dan akan disusutkan secara garis lurus per orang:

$$
\begin{aligned}
\text { Penyusutan per periode } & =\frac{\text { Harga Perolehan }- \text { Estimasi Nilai Residu }}{\text { Estimasi Masa Manfaat }} \\
& =\frac{\mathrm{Rp} 14.545 .000-\mathrm{Rp} .00}{7} \\
& =\mathrm{Rp} 2.077 .857
\end{aligned}
$$

Maka nilai penyusutan pertahun sebesar Rp2.077.857 Perhitungan tersebut belum diterapkan sepenuhnya pada semua aset tetap di BPKAD Bone Bolango. Kebijakan penyusutan setengah tahunan digunakan dalam laporan penyusutan aset tetap, sehingga untuk nilai penyusutan tahunan dibagi dua :

$$
\begin{aligned}
& =\frac{\operatorname{Rp~} 14.545 .000-R p .000}{7} \\
& =\operatorname{Rp} 2.077 .857 \\
& =\frac{\operatorname{Rp} 2.077 .857}{2} \\
& =\operatorname{Rp} 1.038 .929
\end{aligned}
$$

Nilai penyusutan tercatat dalam laporan penyusutan sebesar Rp 1.038.929. Perhitungan ini berlaku untuk semua aset tetap yang ada di BPKAD Bone Bolango. Dengan demikian, jurnal untuk mencatat penyusutan aset bermotor adalah sebagai berikut:

Beban Penyusutan (D) Rp 1.038.929

Akumulasi Penyusutan (K)

Untuk mengetahui penyusutan Per Semester adalah:

$\operatorname{Rp} 1.038 .929$

Nilai Perolehan : Masa Manfaat

$$
2
$$

\begin{tabular}{|c|c|c|c|c|c|c|c|}
\hline $\begin{array}{c}\text { Nama } \\
\text { Aset }\end{array}$ & Tahun & $\begin{array}{c}\text { Nilai } \\
\text { Perolehan }\end{array}$ & $\begin{array}{c}\text { Estimasi } \\
\text { Nilai } \\
\text { Residu }\end{array}$ & $\begin{array}{c}\text { Nilai } \\
\text { Manfaat }\end{array}$ & $\begin{array}{c}\text { Penyusutan } \\
\text { /tahun }\end{array}$ & $\begin{array}{l}\text { Akumulasi } \\
\text { Nilai } \\
\text { Penyusutan }\end{array}$ & Nilai Buku \\
\hline \multirow{8}{*}{$\begin{array}{l}\text { Sepeda } \\
\text { Motor }\end{array}$} & 0 & & & & & & Rp 17.910.000 \\
\hline & 1 & Rp 17.910 .000 & $\mathrm{Rp}-$ & 7 & Rp 2.558.571 & $\operatorname{Rp} \quad 2.558 .571$ & Rp 15.351.429 \\
\hline & 2 & Rp 17.910.000 & $\mathrm{Rp}-$ & 7 & Rp 2.558.571 & Rp $\quad 5.117 .143$ & Rp 12.792.857 \\
\hline & 3 & Rp 17.910.000 & $\mathrm{Rp}-$ & 7 & Rp 2.558.571 & Rp $\quad 7.675 .714$ & Rp 10.234.286 \\
\hline & 4 & Rp 17.910.000 & $\mathrm{Rp}-$ & 7 & Rp 2.558.571 & Rp 10.234.286 & Rp 7.675 .714 \\
\hline & 5 & Rp 17.910.000 & $\mathrm{Rp}-$ & 7 & Rp 2.558.571 & Rp 12.792.857 & Rp 5.117 .143 \\
\hline & 6 & Rp 17.910 .000 & $\mathrm{Rp}-$ & 7 & Rp 2.558.571 & Rp 15.351.429 & $\begin{array}{ll}\mathrm{Rp} & 2.558 .571\end{array}$ \\
\hline & 7 & Rp 17.910.000 & $\mathrm{Rp}-$ & 7 & Rp 2.558.571 & Rp 17.910.000 & $\mathrm{Rp}$ \\
\hline
\end{tabular}

Sedangkan Akumulasi penyusutan per 31 Desember $=$ nilai penyusutan tahunan + akumulasi penyusutan per 1 Januari 2020. Sedangkan nilai buku = biaya perolehan - akumulasi penyusutan per 31 Desember 2020. Sehingga nilai buku untuk kendaraan sepeda motor pada 31 Desember 2020 yang tercatat adalah sebesar Rp 1.904.702, sedangkan berdasarkan perhitungan menggunakan garis lurus seharusnya sebesar Rp 2.077.857 dari masa manfaat.

Tabel 2 Penyusutan Aset Tetap dengan metode garis lurus "Straight line Metodh"

Sumber: Olahan Data, 2021

Data tabel 2 menunjukkan bahwa harga perolehan Sepeda Motor berdasarkan sub buku besar yang telah sesuai dengan KIB yakni sebesar Rp 17.910.000, yang dibeli tahun 2017 dengan kondisi baik, prinsip akuntansi dan penilaian masa manfaat sesuai peraturan Menkeu No. 59/KMK.6/2013 melihat masa manfaat sepeda motor untuk kendaraan bermotor transportasi darat 7 tahun yang lalu dan akan disusutkan secara garis lurus per orang: 
Penyusutan per periode $=$ Harga Perolehan - Estimasi Nilai Residu Estimasi Masa Manfaat

$$
\begin{aligned}
& =\frac{\operatorname{Rp} 17.910 .000-\mathrm{Rp} .00}{7} \\
& =\operatorname{Rp} 2.558 .571
\end{aligned}
$$

Maka nilai penyusutan pertahun sebesar Rp2.558.571 Perhitungan tersebut belum sepenuhnya diterapkan pada semua aset tetap di BPKAD Bone Bolango. Kebijakan penyusutan setengah tahunan digunakan dalam laporan penyusutan aset tetap, sehingga untuk nilai penyusutan tahunan dibagi dua:

$$
\begin{aligned}
& =\frac{\operatorname{Rp} 17.910 .000-R p .000}{7} \\
& =\operatorname{Rp} 2.558 .571 \\
& =\frac{R p 2.558 .571}{2} \\
& =\operatorname{Rp~1.279.286.~}
\end{aligned}
$$

Nilai penyusutan yang dicatat pada laporan penyusutan sebesar Rp1.279.286. Perhitungan tersebut diterapkan pada semua Aset Tetap yang terdapat di BPKAD Bone Bolango. Dengan demikian, maka jurnal untuk mencatat penyusutan asset tetap kendaraan bermotor adalah sebagai berikut:

Beban Penyusutan (D)

Rp 1.279.286

Akumulasi Penyusutan (K) Rp 1.279.286

Untuk mengetahui penyusutan Per Semester adalah:

$$
\frac{\text { Nilai Perolehan : Masa Manfaat }}{2}
$$

Sedangkan Akumulasi penyusutan per 31 Desember $=$ nilai penyusutan

\begin{tabular}{|c|c|c|c|c|c|c|c|}
\hline $\begin{array}{c}\text { Nama } \\
\text { Aset }\end{array}$ & Tahun & $\begin{array}{c}\text { Nilai } \\
\text { Perolehan }\end{array}$ & $\begin{array}{c}\text { Estimasi } \\
\text { Nilai } \\
\text { Residu }\end{array}$ & $\begin{array}{c}\text { Nilai } \\
\text { Manfaat }\end{array}$ & $\begin{array}{c}\text { Penyusutan } \\
\text { /tahun }\end{array}$ & $\begin{array}{c}\text { Akumulasi } \\
\text { Nilai } \\
\text { Penyusutan }\end{array}$ & Nilai Buku \\
\hline \multirow{8}{*}{$\begin{array}{l}\text { Sepeda } \\
\text { Motor }\end{array}$} & 0 & & & & & & Rp 21.600 .000 \\
\hline & 1 & Rp 21.600.000 & $\mathrm{Rp}-$ & 7 & Rp 3.085 .714 & 3.085 .714 & Rp 18.514 .286 \\
\hline & 2 & Rp 21.600.000 & $\mathrm{Rp}-$ & 7 & Rp 3.085 .714 & 6.171 .429 & $\begin{array}{ll}\mathrm{Rp} & 15.428 .571 \\
\end{array}$ \\
\hline & 3 & Rp 21.600.000 & $\mathrm{Rp}-$ & 7 & Rp 3.085 .714 & 9.257 .143 & $\begin{array}{ll}\mathrm{Rp} & 12.342 .857\end{array}$ \\
\hline & 4 & Rp 21.600 .000 & $\mathrm{Rp}-$ & 7 & Rp 3.085 .714 & Rp 12.342 .857 & Rp 9.257 .143 \\
\hline & 5 & Rp 21.600 .000 & $\mathrm{Rp}-$ & 7 & Rp 3.085 .714 & Rp 15.428 .571 & 6.171 .429 \\
\hline & 6 & Rp 21.600.000 & $\mathrm{Rp}-$ & 7 & Rp 3.085 .714 & Rp 18.514 .286 & Rp $\quad 3.085 .714$ \\
\hline & 7 & Rp 21.600.000 & $\mathrm{Rp}-$ & 7 & Rp 3.085 .714 & Rp 21.600 .000 & $\mathrm{Rp}$ \\
\hline
\end{tabular}
tahunan + akumulasi penyusutan per 1 Januari 2020. Sedangkan nilai buku = biaya perolehan - akumulasi penyusutan per 31 Desember 2020. Sehingga nilai buku untuk kendaraan sepeda motor pada 31 Desember 2020 yang tercatat adalah sebesarRp 9.381.427, sedangkan berdasarkan perhitungan menggunakan saldo menurun seharusnya sebesar Rp 10.234.286 dari masa manfaat.

Tabel 3 Penyusutan Aset Tetap dengan metode garis lurus "Straight line Metodh"

Sumber: Olahan Data, 2021

Data tabel 3 menunjukkan bahwa harga perolehan Sepeda Motor berdasarkan sub buku besar yang telah sesuai dengan KIB yakni sebesar Rp 21.600.000, Dibeli tahun 2020 dengan kondisi baik, prinsip akuntansi untuk masa manfaat berdasarkan ordonansi Menkeu no 59/KMK masa 7 tahun dengan metode penyusutan garis lurus: 
Penyusutan per periode $=$ Harga Perolehan - Estimasi Nilai Residu

$$
=\frac{\mathrm{Rp} 21.600 .000-\mathrm{Rp} .00}{7}
$$$$
=\operatorname{Rp} 3.085 .714
$$

Maka nilai penyusutan pertahun sebesar Rp3.085.714 Perhitungan tersebut belum diterapkan pada semua aset tetap di BPKAD Bone Bolango. Kebijakan penyusutan setengah tahunan digunakan dalam laporan penyusutan aset tetap, sehingga untuk nilai penyusutan tahunan dibagi dua:

$$
\begin{aligned}
& =\frac{\operatorname{Rp} 21.600 .000-R p .000}{7} \\
& =\operatorname{Rp} 3.085 .714 \\
& =\frac{R p 3.085 .714}{2} \\
& =\operatorname{Rp~1.542.857~}
\end{aligned}
$$

Jadi nilai penyusutan dalam perhitungan penyusutan adalah Rp 1.542.857. Perhitungan ini diterapkan pada semua Aset yang berada di BPKAD Bone Bolango. Dengan demikian, maka jurnal untuk mencatat penyusutan asset tetap kendaraan bermotor adalah:

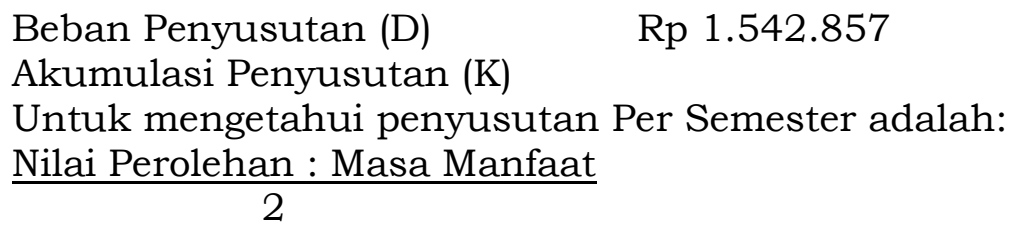

Sedangkan Akumulasi penyusutan per 31 Desember $=$ nilai penyusutan tahunan + akumulasi penyusutan per 1 Januari 2020. Sedangkan nilai buku = biaya perolehan - akumulasi penyusutan per 31 Desember 2020. Sehingga nilai buku untuk kendaraan sepeda motor pada 31 Desember 2020 yang tercatat adalah sebesar Rp 19.028.572, sedangkan berdasarkan perhitungan menggunakan saldo menurun seharusnya sebesar Rp. 18.514.286 dari masa manfaat.

\begin{tabular}{|c|c|}
\hline BPKAD Kab Bone Bolango & PSAP Nomor 7 \\
\hline 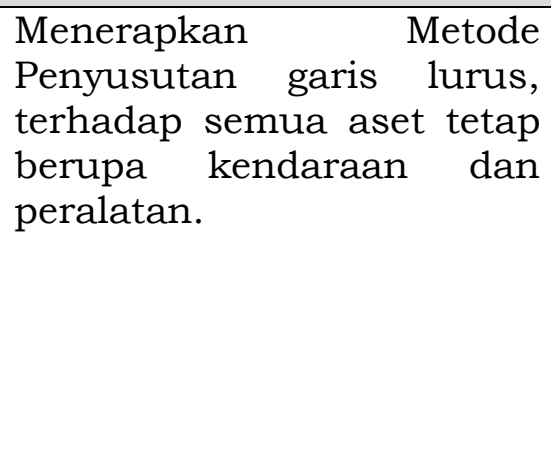 & $\begin{array}{l}\text { Metode Penyusutan yang } \\
\text { di anjurkan: } \\
\text { 1. Metode garis lurus } \\
\text { 2. Metode saldo } \\
\text { menurun berganda } \\
\text { 3. Metode unit produksi. } \\
\text { Entitas pemerintah } \\
\text { dapat memilih salah } \\
\text { satu dari ketiganya. }\end{array}$ \\
\hline
\end{tabular}

\section{Pembahasan}

Berdasarkan hasil analisis sebelumnya maka selanjutnya disajikan penerapan akuntansi penyusutan kendaraan bermotor yang dilakukan oleh BPKAD Kabupaten Bone Bolango dan yang tertuang pada PSAP No. 07.

Tabel 4 Metode Penyusutan

Sumber: Data Olahan, 2021 
Dapat dilihat dari tabel 4 bahwa perhitungan penyusutan terhadap aset tetap pada BPKAD berdasarkan metode garis lurus. Penerapan metode ini mengacu pada rekomendasi PSAP Nomor 07.

Tabel 5 Masa Manfaat

\begin{tabular}{|c|c|c|}
\hline BPKAD Kab Bone Bolango & PSAP Nomor 7 & Ket \\
\hline $\begin{array}{l}\text { Acuan masa manfaat aset } \\
\text { tetap mengikuti peraturan } \\
\text { Menkeu } \\
59 / \text { KMK.6/2013 No. } \\
\text { diterapkan pada aset tetap } \\
\text { peralatan dan mesin. }\end{array}$ & $\begin{array}{l}\text { Entitas pemerintah dapat } \\
\text { mengacu tabel masa } \\
\text { manfaat aset tetap yang } \\
\text { tertuang pada peraturan } \\
\text { Menkeu } \\
\text { 59/KMK.6/2013. No. }\end{array}$ & sesuai \\
\hline
\end{tabular}

Sumber: Data Olahan, 2021

Di lembaga negara, penetapan masa manfaat aset sudah ditetapkan guna memudahkan penentuan masa manfaat aset tersebut seperti yang tertuang pada peraturan Menkeu No. 59/KMK.6/2013. Begitu pula dengan yang dilakukan BPKAD Kabupaten Bone Bolango, yang penerapan masa manfaat peralatan dan mesinnya seperti yang dijelaskan pada tabel 5 .

Tabel 6 Nilai Buku

\begin{tabular}{|c|c|c|}
\hline BPKAD Kab Bone Bolango & PSAP Nomor 7 & Ket \\
\hline $\begin{array}{lr}\text { Penentuan nilai } & \text { buku } \\
\text { untuk aset } & \text { tidak } \\
\text { menurunkan } & \text { harga } \\
\text { perolehan aset dengan } \\
\text { akumulasi penyusutan }\end{array}$ & $\begin{array}{l}\text { Penentuan nilai buku } \\
\text { aset dihitung dari harga } \\
\text { perolehan suatu aset } \\
\text { setelah dikurangi dengan } \\
\text { akumulasi penyusutan }\end{array}$ & Belum Sesuai \\
\hline
\end{tabular}

Sumber: Data Olahan, 2021

PSAP No 7 menjelaskan bahwa untuk nilai buku setiap aset dihitung dari harga perolehan suatu aset setelah aset tersebut dikurangi dengan akumulasi penyusutan. Sementara hal tersebut belum sesuai dengan penetapan nilai buku aset pada BPKAD Kabupaten Bone Bolango yaitu dengan tidak menurunkan harga perolehan aset dikurangi akumulasi penyusutan.

Tabel 7 Lembaga Yang Membuat Perhitungan Penyusutan

\begin{tabular}{lrlr}
\hline BPKAD Kab Bone Bolango & \multicolumn{1}{c}{ PSAP Nomor 7 } & Ket \\
\hline Kegiatan perhitungan serta & Peraturan Pemerintah No 71 & \\
pelaporan akuntansi & tahun & 2010 & \\
penyusutan aset tetap & merekomendasikan entitas & \\
dilakukan oleh BPKAD & pemerintah sebagai lembaga & Sesuai \\
Kabupaten Bone Bolango. & yang mandiri dan dapat & \\
& mengatur seluruh aktivitas & \\
& akuntansinya secara mandiri & \\
& sesuai asas kemandirian.
\end{tabular}

Sumber: Data Olahan, 2021 
Berdasarkan tabel 7 disebutkan bahwa kegiatan perhitungan penyusutan dan pembukuan yang dilakukan oleh BPKAD Kabupaten Bone Bolango, hal ini tidak bertentangan dengan Peraturan Pemerintah Nomor 71 Tahun 2010, yang diadopsi Independensi Perusahaan, artinya seluruh unit entitas organisasi dipandang sebagai unit independen serta wajib menyusun laporan keuangan sedemikian rupa sehingga tidak terjadi kesalahan penyajian dalam pelaporan keuangan antar unit instansi pemerintah.

\section{Kesimpulan Dan Saran}

Kesimpulan dari artikel ini yakni bahwa dalam aktivitas akuntansi penyusutan aset khususnya kenderaan bermotor pada BPKAD Kabupaten Bone Bolango telah menggunakan metode pencatatan garis lurus dan hal ini tidak bertentangan dengan PSAP Nomor 7. Selanjutnya untuk penerapan masa manfaat aset telah mengacu masa manfaat yang tertuang dalam PMK No. 59/KMK.6/2013. Adapun penetapan dalam menentukan nilai buku aset belum sesuai karena BPKAD Kabupaten Bone Bolango tidak menurunkan harga perolehan aset dengan akumulasi penyusutan. Untuk kegiatan perhitungan penyusutan aset kenderaan bermotor secara kelembagaan BPKAD melakukan pencatatan perhitungan serta pelaporan akuntansi untuk penyusutan aset.

Saran untuk BPKAD Kabupaten Bone Bolango agar penentuan nilai buku aset dapat dihitung mulai dari harga perolehan aset sampai aset telah dikurangi akumulasi penyusutan sebagaimana dijelaskan dalam PSAP No 7.

\section{Daftar Pustaka}

Biswan, A. T., \& Falaqi, F. (2018). Praktik Akuntansi Aset Tetap Pada Pemerintah Kabupaten Boyolali Provinsi Jawa Tengah. Otonomi Keuangan Daerah, 6(17), 39-63.

Effendi, R. (2015). Analisis Perlakuan Akuntansi atas Aset Tetap Berdasarkan SAK ETAP Pada CV. Sekonjing Ogan Ilir. Jurnal Ilmiah STIE MDP, 5(1), 1-8.

Hasan, W., \& Lamatenggo, Y. (2018). Penyusutan Mesin Produksi Terhadap Biaya Overhead Pabrik. Gorontalo Accounting Journal, 1(2), 35-43.

Ibrahim. (2015). Metodologi Penelitian Kualitatif. Bandung: Alfabeta.

Khafiyya, N. A. (2016). Akuntansi Aset Tetap (PSAP 07) Pada Dinas Pendapatan Daerah Provinsi Kalimantan Timur. Ekonomia, 5(3). http://ejurnal.untagsmd.ac.id/index.php/EKM/article/view/2522

Peraturan Menteri Keuangan Nomor 01/PMK.06/2013 Tahun 2013 tentang Penyusutan Barang Milik Negara Berupa Aset tetap Pada Entitas Pemerintah Pusat.

166/PMK.06/2015 Tahun 2015 tentang Barang Milik Negara.

Peraturan Pemerintah Nomor 71 Tahun 2010 tentang Standar Akuntansi Pemerintah. Jakarta: Salemba Empat.

Pernyataan Standar Akuntansi Pemerintah Nomor 07 tentang Akuntansi Aset tetap.

Putri, R. A. F., Sari, Y. P., \& Sulistyowati, D. (2016). Analisis Perlakuan Akuntansi Aset Tetap Berdasarkan Pernyataan Standar Akuntansi Pemerintahan No 07 pada Badan Penanggulangan Bencana Daerah Kabupaten Tegal. Politeknik Negeri Jakarta, 07, 508-513.

Rais, A., Ahmad, I. H., \& Iskandar, S. (2020). Penerapan Akuntansi Aset Tetap PSAP 07 Pada Kantor Inspektorat Kabupaten Bantaeng. Accounting Journal, 01(01), 191-198. 
Soepiansyah M, Ady. 2014. Implementasi Pernyataan Standar Akuntansi Pemerintah No. 07 Tentang Akuntansi Penyusutan Aset Tetap Pada Kantor Satuan Polisi Pamong Praja Provinsi Kalimantan Barat. Pontianak. Jurnal Kajian Ilmiah Akuntansi Fakultas Ekonomi UNTAN (KIAFE) Vol 3, No 2.

Sugiyono. (2008). Metode Penelitian Kuantitatif, Kualitatif Dan R\&D. Jakarta: Alfabeta. 